\title{
PENINGKATAN KETERAMPILAN GURU DALAM MENYUSUN RENCANA PELAKSANAAN PEMBELAJARAN MELALUI LATIHAN DAN BIMBINGAN
}

\author{
SITI JUWARIAH \\ SDN MOJODANU II NGUSIKAN JOMBANG \\ Email: sitijuwariahngusikan@gmail.com
}

\begin{abstract}
Teacher qualifications, even though they are bachelor, do not guarantee that each teacher is able to draw up a Learning Implementation Plan (RPP), as evidenced by the 8 teachers in SD Negeri Mojodanu II Ngombang District, Jombang, which are still $25 \%$ capable of preparing lesson plans independently, so supervision activities related to academic supervision in the preparation of the RPP . These conditions are influenced by: (1) teacher busyness, (2) lack of training and guidance as well as mentoring and (3) lack of socialization. Related to the above problems, there needs to be adequate handling assistance. In this case the effort made is to carry out training and guidance, which aims at improving teacher skills in the preparation of RPP according to SNP independently. Data analysis was carried out using qualitative descriptive analysis. The study was conducted in stages of the cycle, each cycle consisting of 4 (four) steps including: planning, implementation, observation and reflection. The results of this study, 8 teachers from schools that were the subjects of the study, all showed increased competency in accordance with established indicators of success. Suggestions proposed are: (1) it is necessary to intensify the improvement of teacher skills in preparing lesson plans through mentoring activities or the like (2) the need for means such as IHT, so that they can exchange experiences through academic dialogue.
\end{abstract}

Keywords: Teacher Skills, Arranging RPP, Training and Guidance

Abstrak: Kualifikasi guru, meskipun mereka lulusan perguruan tinggi, tidak menjamin bahwa setiap guru mampu menyusun rencana pelaksanaan pembelajaran (RPP), sebagaimana dibuktikan oleh 8 guru di SD Negeri Mojodanu II Ngombang, Jombang, yang masih 25\% mampu menyusun rencana pembelajaran secara mandiri, sehingga kegiatan pengawasan yang berkaitan dengan pengawasan akademik dalam penyusunan RPP. Kondisi ini dipengaruhi oleh: (1) kesibukan guru, (2) kurangnya pelatihan dan bimbingan, serta pendampingan dan (3) kurangnya sosialisasi. Terkait masalah di atas, perlu bantuan penanganan yang sesuai. Dalam hal ini upaya yang dilakukan adalah untuk melaksanakan Pelatihan dan bimbingan, yang bertujuan untuk meningkatkan keterampilan guru dalam penyusunan RPP menurut SNP secara mandiri. Analisis data dilakukan dengan menggunakan analisis deskriptif kualitatif. Penelitian ini dilakukan dalam tahap siklus, setiap siklus yang terdiri dari 4 (empat) langkah termasuk: perencanaan, pelaksanaan, observasi dan refleksi. Hasil kajian ini, 8 guru dari sekolah yang menjadi subyek kajian, semuanya menunjukkan peningkatan kompetensi sesuai dengan indikator keberhasilan yang ditetapkan. Usulan yang diusulkan adalah: (1) perlu untuk mengintensifkan peningkatan keterampilan guru dalam mempersiapkan rencana pembelajaran melalui kegiatan pendampingan atau semacamnya (2) kebutuhan untuk sarana seperti IHT, sehingga mereka dapat bertukar pengalaman melalui dialog akademik.

Kata kunci: kompetensi guru, penyusunan RPP, bimbingan dan pelatihan 
DOI : $10.26740 / j d m p . v 4 n 2 . p 79-86$

Peraturan Menteri Pendidikan Nasional Nomor 13 tahun 2007 tentang Standar Kepala Sekolah/Madrasah, yang berisi standar kualifikasi dan kompetensi kepala sekolah. Standar kompetensi berisi seperangkat kemampuan yang harus dimiliki dan dikuasai kepala sekolah untuk dapat melaksanakan tugas pokok, fungsi dan tanggung jawabnya. Ada lima dimensi kompetensi yang harus dikuasai kepala sekolah yakni: (a) kompetensi kepribadian, (b) kompetensi supervisi manajerial, (c) kompetensi supervisi akademik, (d) kompetensi kewirausahaan (e) kompetensi sosial (Sudjana, 2009).

Kepala sekolah merupakan tenaga kependidikan profesional yang berfungsi sebagai unsur pelaksana supervisi pendidikan yang mencakup supervisi akademik dan supervisi manajerial. Supervisi akademik terkait dengan tugas pembinaan guru dalam meningkatkan kualitas proses pembelajaran. Supervisi manajerial terkait dengan tugas pembinaan kepala sekolah dan tenaga kependidikan lainnya dalam aspek pengelolaan dan administrasi sekolah.

Berdasarkan tugas pokok kepala satuan pendidikan, maka ruang lingkup kegiatan dalam program pengawasan adalah sebagai Penilaian kinerja yang akan dilakukan terhadap, pendidik (guru) dan tenaga kependidikan lain (tenaga administrasi, tenaga laboratorium, dan tenaga perpustakaan). Guru dalam hal perencanaan, pelaksanaan dan penilaian proses pembelajaran/bimbingan berdasarkan kurikulum yang berlaku. Untuk itu peran guru sangat penting dalam proses belajar mengajar karena guru sebagai fasilitator yang mengelola proses pembelajaran di kelas mempunyai andil dalam menentukan kualitas pendidikan. Konsekuensinya adalah guru harus mempersiapkan ( merencanakan) segala sesuatu agar proses pembelajaran di kelas berjalan dengan efektif. Untuk itu, guru perlu menyusun Rencana Pelaksanaaan
Pembelajaran terlebih dahulu karena dengan rencana pelaksanaan pembelajaran tujuan pembelajaran tersebut dapat tercapai.Selain itu dalam penyiapan perencanaan pembelajaran dipengaruhi oleh hasil pembinaan dan supervise Kepala (Pidarta, 1992).

Di sisi lain berdasarkan pemantauan penulis, masih banyak guru yang tidak melaksanakan tugas pokok dan fungsinya dengan baik. Kita tahu bahwa berdasarkan Peraturan Pemerintah Nomor 74 tahun 2008, tentang Guru Pasal 52 ayat (1) mencakup kegiatan pokok yaitu merencanakan pembelajaran, melaksanakan pembelajaran, menilai hasil pembelajaran, membimbing dan melatih peserta didik, serta melaksanakan tugas tambahan yang melekat pada pelaksanaan tugas pokok. Akan tetapi kenyataanya tidak semua guru melakukan itu. Guru mengajar tanpa persiapan, perencanaan, dan tindak lanjut. Masih banyak guru yang belum bisa menyusun rencana pembelajaran, memilih metode, media, dan model pembelajaran dengan baik, sehingga dapat kita bayangkan bagaimana hasil pembelajarannya. Sudah barang tentu tujuan pembelajaran yang telah diamanatkan oleh undang-undang tidak akan tercapai.

Berdasarkan pengamatan dilapangan $50 \%$ dari 8 guru, di SD Negeri Mojodanu IImasih belum mampu menyusun perencanaan pembelajaran secara mandiri karena masih banyak guru yang mengadopsi dari RPP orang lain (Nurhadi, 2004). Dengan demikian, perlu diadakan supervisi atau pembinaan berupa latihan dan bimbingan (LATBIM) terhadap guru dalam penyusunan Rencana Pelaksanaan Pembelajaran (RPP) yang lengkap sesuai dengan KTSP 2006. Adapun Komponen RPP antara lain Identitas Mata pelajaran, Standar Kompetensi (SK), Kompetensi Dasar (KD), Indikator Pencapaian kompetensi, tujuan pembelajaran, materi ajar, alokasi waktu, metode pembelajaran, kegiatan pembelajaran, penilaian hasil belajar, dan sumber belajar (Dewi, 2009). 
Berdasarkan uraian di atas, penulis mencoba mencurahkan pengalaman berdasarkan pengamatan dilapangan, dalam pelaksanaan supervisi akademik guna meningkatakan keterampilan guru dalam penyusunan RPP yang dilaksanakan guru dalam proses belajar mengajar melaui kegiatan latihan dan bimbingan (LATBIM).

Tujuan penelitian ini adalah untuk meningkatkan keterampilan guru dalam menyusun RPP di Sekolah Dasar Negeri Mojodanu II kecamatan Ngusikan Jombang melalui kegiatan pelatihan dan bimbingan (LATBIM).

\section{Landasan Teori}

Keterampilan mengajar guru merupakan hal yang penting dalam proses pembelajaran. Keterampilan mengajar guru merupakan seperangkat kemampuan/kecakapan guru dalam melatih/membimbing aktivitas dan pengalaman seseorang serta membantunya berkembang dan menyesuaikan diri kepada lingkungan. Untuk itu, agar terwujudnya keterampilan guru dalam melakukan proses pembelajaran yang baik, guru harus mampu menyusun rencana pelaksanaan pembelajaran secara mandiri (Zuriah et al., 2016). Karena dengan rencana pelaksanaan pembelajaran tugas dan peran guru di kelas dapat tercapai.

Permendiknas No. 103 tahun 2014 menyatakan, "Rencana Pelaksanaan Pembelajaran (RPP) adalah rencana yang menggambarkan prosedur dan pengorganisasian pembelajaran untuk mencapai satu kompetensi dasar dalam beberapa pertemuan yang mengacu pada standar isi, standar kelulusan dan telah dijabarkan dalam silabus" (Sa'bani, 2017). Berdasarkan pendapat di atas dapat disimpulkan bahwa perencanaan pembelajaran adalah suatu penyusunanrencana pembelajaran yang akan dilaksanakan dalam proses kegiatan pembelajaran untuk mencapai tujuan yang telah ditetapkan dalam kurikulum.

Permendiknas No. 103 Tahun 2014 menyatakan dalam menyusun rencana pelaksanaan pembelajaran harus memperhatikan prinsip-prinsip sebagai berikut: a) memperhatikan perbedaan individu peserta didik, b) mendorong partisipasi aktif peserta didik, c) mengembangkan budaya membaca dan menulis, d) memberikan umpan balik dan tindak lanjut, e) keterkaitan dan keterpaduan, f) menerapkan teknologi informasi dan komunikasi RPP (Kusumawati, 2016) dan (Zarkasi, 2019).

Pelatihan dan bimbingan (LATBIM) merupakan gabungan kegiatan pelatihan dan bimbingan yaitu serangkaian kegiatan yang dapat meningkatkan keterampilan disertai dengan pemberian bantuan kepada individu dalam melakukan peningkatan keterampilan tersebut (Eliyanto \& Wibowo, 2013).

Dalam pelatihan dan bimbingan yang dilakukan peneliti ini adalah pemberian serangkaian kegiatan dan bantuan dalam penyusunan RPP yang baik. Kegiatan LATBIM diselenggarakan di SDN Mojodanu II bertujuan untuk meningkatkan keterampilan guru SDN Mojodanu II dalam membuat RPP sesuai KTSP 2006. LATBIM di SDN Mojodanu II ini akan dilaksanakan dalam bentuk workshop, dan praktek langsung di kelas.

\section{METODE}

\section{Tempat Penelitian}

Penelitian Tindakan Sekolah dilaksanakan di sekolah sendiri berstatus negeri yaitu SDN Mojodanu II. Pemilihan sekolah tersebut bertujuan untuk meningkatkan ketrampilan guru dalam penyusunan RPP di SD Negeri Mojodanu II kec. Ngusikan Jombang melalui kegiatan kepelatihan.

\section{Waktu Penelitian}

PTS ini dilaksanakan pada semester dua tahun pelajaran 2017/2018 selama kurang lebih satu setengah bulan mulai 3 Januari 2018 sampai dengan 24 Pebruari 2018. 
DOI : $10.26740 / j d m p . v 4 n 2 . p 79-86$

\section{Siklus Penelitian}

Penelitian Tindakan Sekolah dilaksanakan melalui dua siklus untuk melihat pelaksanaan supervisi akademik sehingga dapat meningkatkan ketrampilan guru dalam penyusunan RPP.

\section{Subjek Penelitian}

Subjek dalam PTS ini adalah delapan guru di SDN II Mojodanu Kecamatan Ngusikan Jombang

\section{Sumber Data}

Sumber data dalam PTS ini adalah rencana pelaksanaan pembelajaran yang sudah dibuat guru.

\section{Teknik Pengumpulan Data}

Teknik pengumpulan data dalam penelitian ini diperoleh melalui wawancara, observasi, dan diskusi.

\section{Prosedur Penelitian}

Jenis penelitian yang dipilih, yaitu penelitian tindakan (action research), maka penelitian ini menggunakan model penelitian tindakan dari (Kemmis et al., 2013), yaitu berbentuk spiral dari siklus yang satu ke siklus yang berikutnya.Setiap siklus meliputi planning (rencana), action (tindakan), observation (pengamatan), dan reflection (refleksi). Langkah pada siklus berikutnya adalah perncanaan yang sudah direvisi, tindakan, pengamatan, dan refleksi.Sebelum masuk pada siklus 1 dilakukan tindakan pendahuluan yang berupa identifikasi permasalahan.

\section{HASIL PENELITIAN}

Pada saat awal siklus pertama indikator pencapaian hasil dari setiap komponen RPP belum sesuai/tercapai seperti rencana/keinginan peneliti. Hal itu dibuktikan dengan masih adanya komponen RPP yang belum dibuat oleh guru.

Siklus kedua juga terdiri dari empat tahap yakni: (1) perencanaan, (2) pelaksanaan, (3) observasi, dan (4) refleksi. Hasil observasi pada siklus kedua dapat dideskripsikan berikut ini:
Observasi dilaksanakan Selasa, 15 Januari 2018, terhadap delapan orang guru. Semuanya menyusun RPP Kurikulum2006, akan tetapi masih ada guru yang salah dalam menentukan kegiatan siswa dalam langkah-langkah kegiatan pembelajaran dan metode pembelajaran, serta tidak memilah/ menguraikan materi pembelajaran dalam sub-sub materi. Untuk komponen penilaian hasil belajar, dapat dikemukakan sebagai berikut.

- Empat orang sudah benar dalam menentukan teknik dan bentuk instrumennya.

- Dua orang kurang jelas dalam menentukan pedoman penskoran.

- Dua orang tidak menuliskan rumus perolehan nilai siswa.

Selanjutnya mereka dibimbing dan disarankan untuk melengkapinya. Kemudian dilihat dari kompetensi guru dalam menyusun RPP Kurikulum 2006, terjadi peningkatan dari siklus ke siklus.

\section{Komponen Identitas}

Pada siklus pertama semua guru (delapan orang) mencantumkan identitas dalam RPP-nya (melengkapi RPP-nya dengan identitas) dengan presentase sebesar $75 \%$. Pada siklus kedua terjadi peningkatan $25 \%$ dari siklus I.

Gambar 1 Data Hasil penilaian komponen Identitas

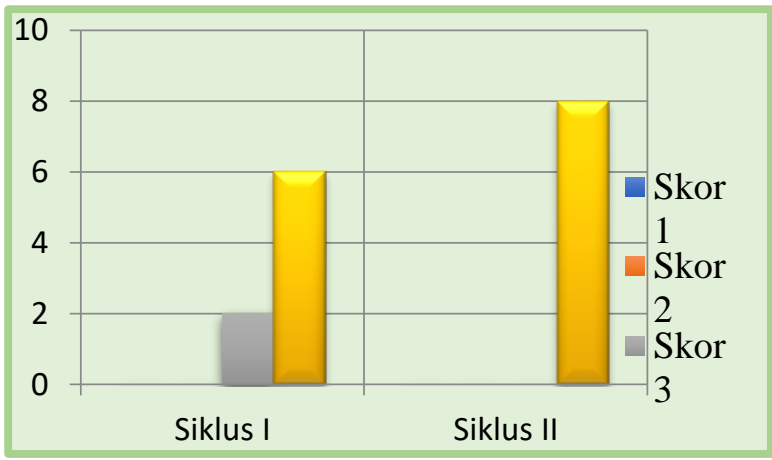

\section{Komponen Standar Kompetensi}

Pada siklus pertama semua guru (delapan orang) mencantumkan standar Kompetensidalam RPP-nya (melengkapi RPP-nya dengan standar kompetensi) 
dengan presentase sebesar $81 \%$. Pada siklus kedua sebesar $94 \%$ yaitu terjadi peningkatan $13 \%$ dari siklus I

Gambar 2 Data Hasil penilaian komponen Standar Kompetensi

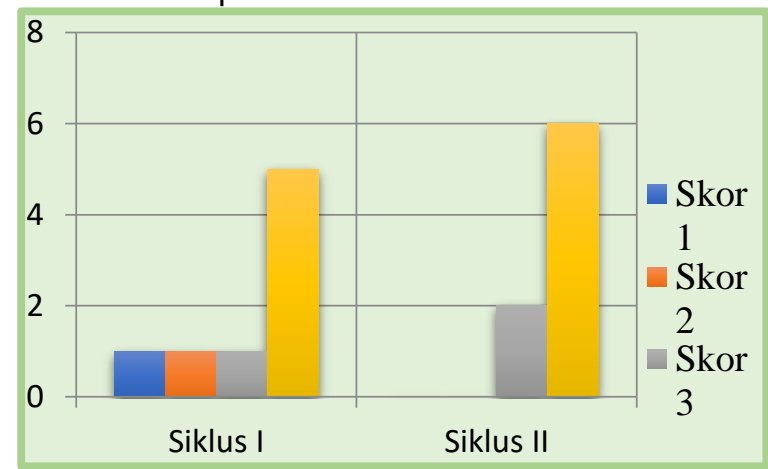

\section{Komponen Kompetensi Dasar}

Pada siklus pertama semua guru (delapan orang) mencantumkan kompetensi dasar dalam RPP-nya (melengkapi RPP-nya dengan kompetensi dasar) dengan presentase $81 \%$. Pada siklus kedua sebesar $94 \%$, terjadi peningkatan $13 \%$ dari siklus I. Grafik 3 Data Hasil penilaian komponen Kompetensi Dasar

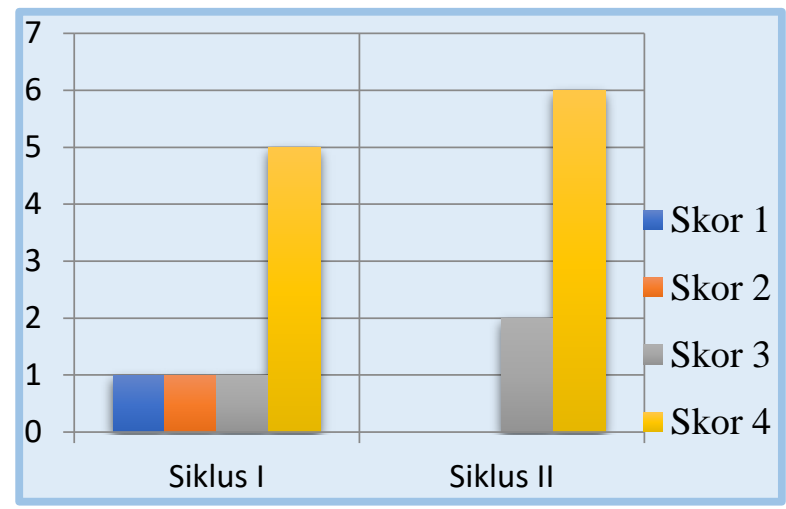

\section{Komponen Indikator Pencapaian} Kompetensi

Pada siklus pertama delapan orang guru mencantumkan indikator pencapaian kompetensi dalam RPP-nya (melengkapi RPP-nya dengan indikator pencapaian kompetensi). Sedangkan satu orang tidak mencantumkan/melengkapinya. Jika dipersentasekan, $56 \%$. Pada siklus kedua sebesar $78 \%$, terjadi peningkatan $22 \%$ dari siklus I.
Gambar 4 Data Hasil penilaian komponen Indikator Pencapain Kompetensi

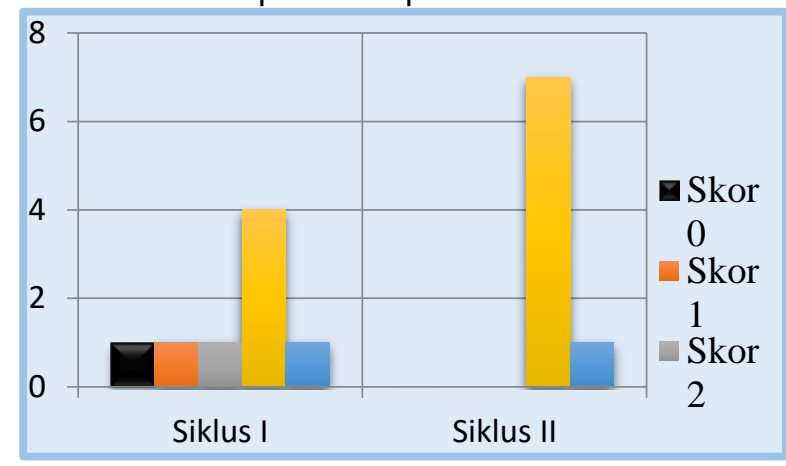

\section{Komponen Tujuan Pembelajaran}

Pada siklus pertama delapan orang guru mencantumkan Tujuan pencapaian kompetensi dalam RPP-nya (melengkapi RPP-nya dengan indikator pencapaian kompetensi). Sedangkan satu orang tidak mencantumkan/melengkapinya. Jika dipersentasekan, 56\%. Pada siklus kedua sebesar $78 \%$, terjadi peningkatan $22 \%$ dari siklus I.

Gambar 5 Data Hasil penilaian komponen Tujuan Pembelajaran

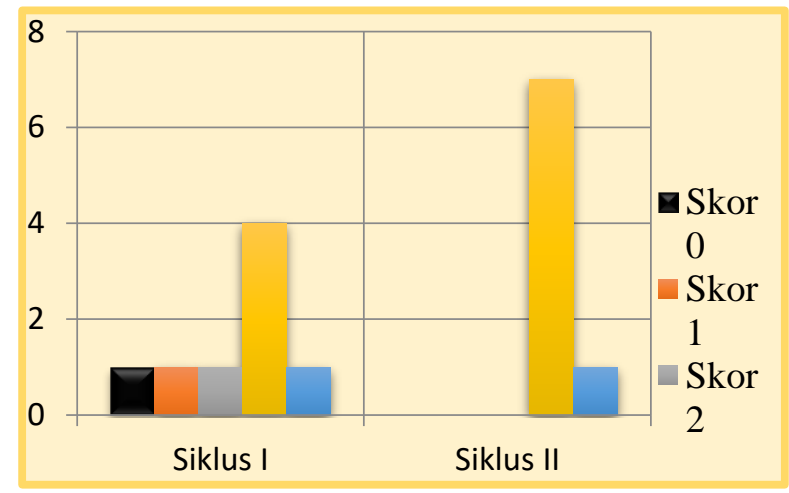

\section{Komponen Materi Ajar}

Pada siklus pertama semua guru (delapan orang) mencantumkan materi ajar dalam RPP-nya (melengkapi RPP-nya dengan materi ajar). Jika dipersentasekan, $66 \%$. Pada siklus sebesar $81 \%$, terjadi peningkatan $15 \%$ dari siklus I.

Gambar 6 Data Hasil penilaian komponen Materi Ajar 


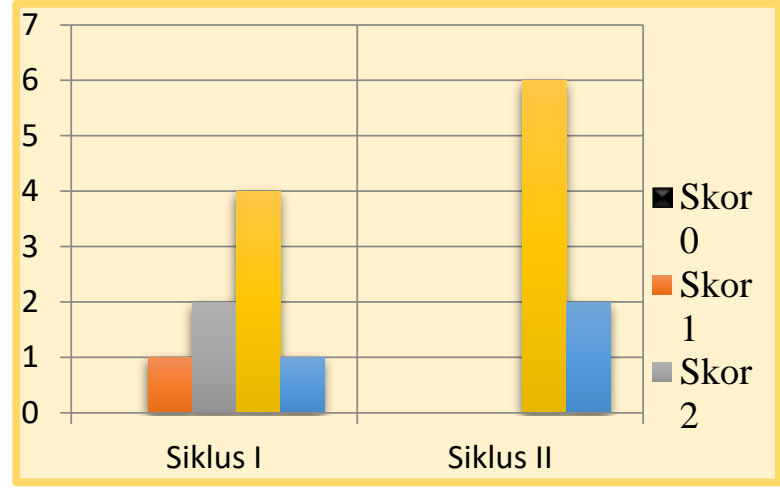

\section{Komponen Alokasi Waktu}

Pada siklus pertama semua guru (delapan orang) mencantumkan alokasi waktu dalam RPP-nya (melengkapi RPP-nya dengan alokasi waktu). Semuanya mendapat skor 3 (baik). Jika dipersentasekan, 75\%. Pada siklus kedua sebesar $91 \%$, terjadi peningkatan $16 \%$ dari siklus I.

Gambar 7 Data Hasil penilaian komponen Alokasi Waktu

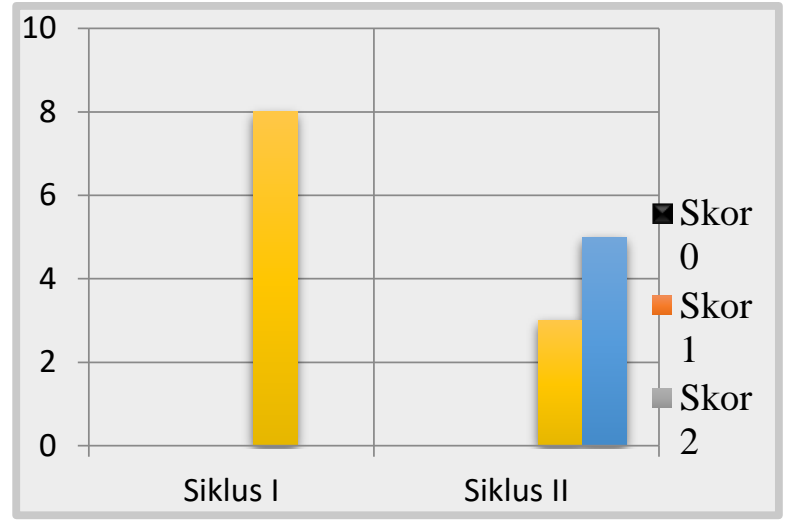

\section{Komponen Langkah-Langkah Kegiatan Pembelajaran}

Pada siklus pertama semua guru (delapan orang) mencantumkan langkahlangkah kegiatan pembelajaran dalam RPPnya (melengkapi RPP-nya dengan langkahlangkah kegiatan pembelajaran). Jika dipersentasekan, 53\%. Pada siklus kedua sebesar $72 \%$, terjadi peningkatan $19 \%$ dari siklus I.
Gambar 8 Data Hasil Penilaian Komponen Langkah-Langkah Kegiatan Pembelajaran

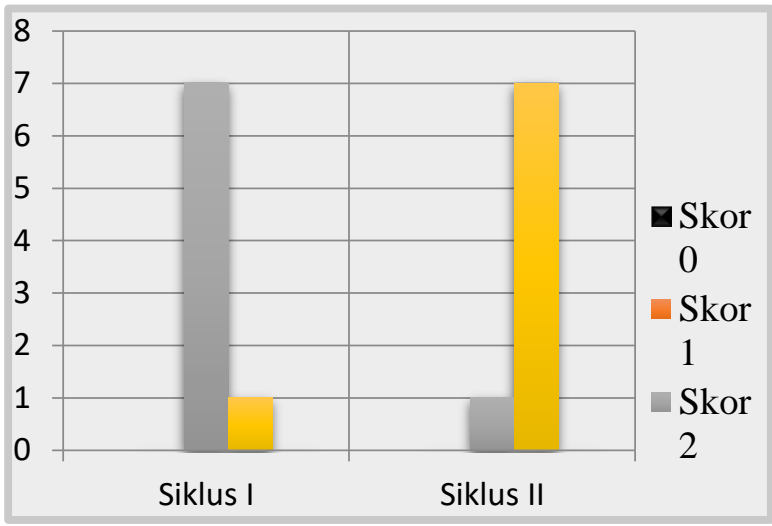

\section{Alat dan Sumber Bahan}

Pada siklus pertama semua guru (delapan orang) mencantumkan alat-alat pembelajaran dalam RPP-nya (melengkapi RPP-nya dengan alat dan sumber belajar pembelajaran). Jika dipersentasekan, 53\%. Pada siklus kedua sebesar $72 \%$, terjadi peningkatan $19 \%$ dari siklus I.

Gambar 9 Data Hasil penilaian komponen Alat dan Sumber Bahan

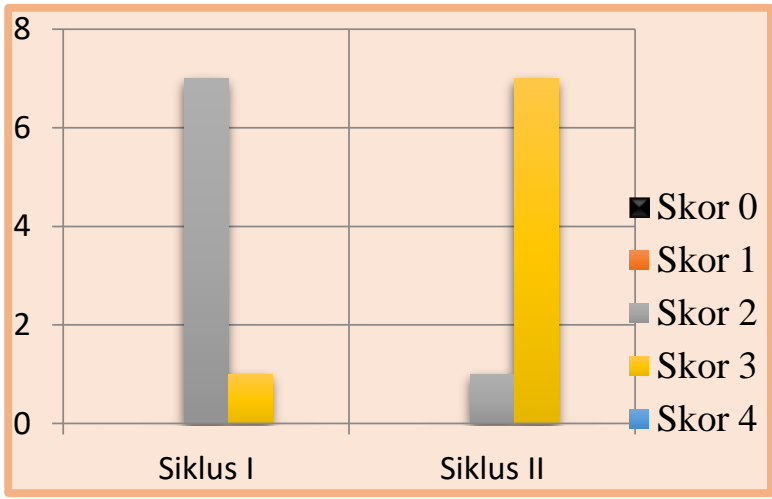

\section{Komponen Hasil Belajar}

Pada siklus pertama semua guru (delapan orang) mencantumkan peSkoran hasil belajar dalam RPP-nya meskipun subsub komponennya (teknik, bentuk instrumen, soal), pedoman penskoran, dan kunci jawabannya kurang lengkap. Jika dipersentasekan, 56\%. Pada siklus kedua sebesar $78 \%$, terjadi peningkatan $22 \%$ dari siklus I. 
Gambar 10 Data Hasil penilaian komponen Hasil

\section{Belajar}

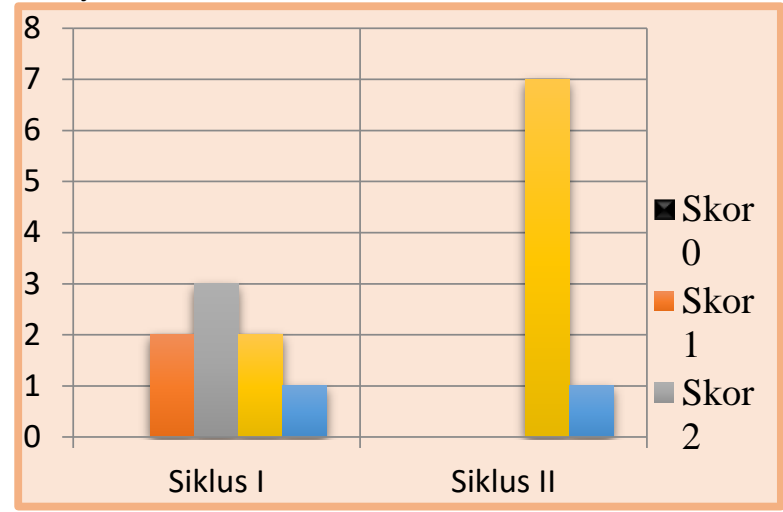

\section{Komponen Sumber Belajar}

Pada siklus pertama semua guru (delapan orang) mencantumkan sumber belajar dalam RPP-nya (melengkapi RPPnya dengan sumber belajar). Jika dipersentasekan, 66\%. Pada siklus kedua sebesar $69 \%$, terjadi peningkatan $3 \%$ dari siklus I.

Gambar 11 Data Hasil penilaian komponen Sumber Belajar

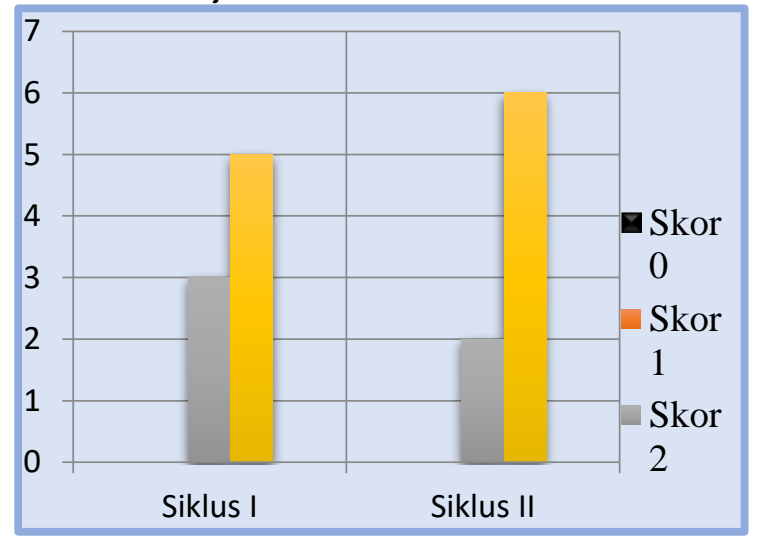

Berdasarkan pembahasan di atas terjadi peningkatan kompetensi guru dalam menyusun RPP. Pada siklus I Skor rata-rata komponen RPP Kurikulum 2006 69\%, pada siklus II Skor rata-rata komponen RPP Kurikulum2006 83\%, terjadi peningkatan $14 \%$.

\section{PEMBAHASAN}

Penelitian Tindakan Sekolah dilaksanakan di SDN Mojodanu II Kecamatan NgusikanKabupaten Jombang yang merupakan sekolah tempat tugas peneliti, terdiri atas delapan guru, dan dilaksanakan dalam dua siklus. Kedelapan guru tersebut menunjukkan sikap yang baik dan termotivasi dalam menyusun RPP Kurikulum 2006 dengan lengkap. Hal ini peneliti ketahui dari hasil pengamatan pada saat melakukan wawancara dan pendampingan penyusunan RPP Kurikulum 2006. Selanjutnya dilihat dari kompetensi guru dalam menyusun RPP Kurikulum 2006, terjadi peningkatan dari siklus ke siklus.

\section{KESIMPULAN}

Berdasarkan hasil Penelitian Tinadakan Sekolah (PTS) dapat disimpulkan sebagai berikut, latihan dan bimbingan dapat meningkatkan motivasi guru dalam menyusun RPP Kurikulum 2006 dengan lengkap. Guru menunjukkan keseriusan dalam memahami dan menyusun RPP Kurikulum2006apalagi setelah mendapatkan bimbingan pengembangan/penyusunan RPP dari peneliti. Informasi ini peneliti peroleh dari hasil pengamatan pada saat mengadakan wawancara dan bimbingan pengembangan/penyusunan RPP Kurikulum 2006 kepada guru.

Latihan dan bimbingan dapat meningkatkan kompetensi guru dalam menyusun RPP Kurikulum 2006. Hal itu dapat dibuktikan dari hasil observasi /pengamatan yang memperlihatkan bahwa terjadi peningkatan kompetensi guru dalam menyusun RPP Kurikulum2006dari siklus ke siklus . Pada siklus I nilai rata-rata komponen RPP Kurikulum 2006 dari 8 guru adalah $62,5 \%$ dan pada siklus II $87,5 \%$. Jadi, hanya satu guru saja yang belum mampu menyusun RPP sesuai kaidah yang benar.

\section{SARAN}

Telah terbukti bahwa dengan latihan dan bimbingan dapat meningkatkan motivasi dan kompetensi guru dalam menyusun RPP Kurikulum 2006. Oleh karena itu, peneliti menyampaikan beberapa saran sebagai berikut.

1. Motivasi yang sudah tertanam khususnya dalam penyusunan RPP 
Kurikulum 2006 hendaknya terus dipertahankan dan ditingkatkan/ dikembangkan.

2. RPP Kurikulum 2006 yang disusun/dibuat hendaknya mengandung komponen-komponen RPP secara lengkap dan baik karena RPP Kurikulum 2006 merupakan acuan/pedoman dalam melaksanakan pembelajaran.

3. Dokumen RPP hendaknya dibuat di awal tahun pelajaran atau awal semester, sebagai acuan dalam melaksanakan proses pembelajaran, sehingga guru yang menggantikan juga dapat melaksanakan dengan baik.

\section{DAFTAR RUJUKAN}

Dewi, K. E. (2009). Pengembangan Bahan Ajar Bahasa dan Sastra Indonesia Dengan Pendekatan Tematis. Universitas Sebelas Maret.

Eliyanto, E., \& Wibowo, U. B. (2013). Pengaruh Jenjang Pendidikan, Pelatihan, Dan Pengalaman Mengajar Terhadap Profesionalisme Guru Sma Muhammadiyah Di Kabupaten Kebumen. Jurnal Akuntabilitas Manajemen Pendidikan, 1(1), 34-47. https://doi.org/10.21831/amp.v1i1.2321

Kemmis, S., McTaggart, R., \& Nixon, R. (2013). The Action Research Planner. Springer.
Kusumawati, H. (2016). Peningkatan Kompetensi Guru Sd Dalam Menyusun Rpp Dan Melaksanakan Pembelajaran Menggunakan Tutor Sejawat. Satya Widya, 32(2), 92-102. https://doi.org/10.24246/j.sw.2016.v32.i 2.p92-102

Nurhadi. (2004). Kurikulum 2004 (Gramedia W).

Pidarta, M. (1992). Pemikiran Tentang Supervisi Pendidikan. Bumi Aksara.

Sa'bani, F. (2017). Peningkatan Kompetensi Guru dalam Menyusun RPP melalui Kegiatan Pelatihan pada MTs Muhammadiyah Wonosari. JURNAL PENDIDIKAN MADRASAH: (Journal of Madrasah Education), 2(1), 13-22. http://ejournal.uinsuka.ac.id/tarbiyah/index.php/JPM/artic le/view/1429\%0Ainternalpdf://0.0.2.29/1429.html

Sudjana, N. (2009). Standar Kompetensi Kepala, Dimensi, dan Indikator. Binamitra Publishing.

Zarkasi, A. (2019). PENINGKATAN KETERAMPILAN GURU DALAM PENYUSUNAN RPP BERBASIS HOTS MELALUI WORKSHOP. Kompetensi, 12(1), 86-96.

Zuriah, N., Sunaryo, H., \& Yusuf, N. (2016). IbM Guru Dalam Pengembangan Bahan Ajar Kreatif Inovatif Berbasis Potensi Lokal. Dedikasi, 13, 39-49. 1693-3214 